\title{
PROFITABILITAS USAHATANI CABAI MERAH (Capsicum annum L.) DI KECAMATAN PANJALU KABUPATEN CIAMIS
}

\author{
Oleh \\ MOCHAMAD RAMDAN \\ Fakultas Pertanian Universitas Galuh Ciamis \\ Email: ramdanmoch@gmail.com
}

\begin{abstract}
Abstrak
Tujuan dari penelitian ini adalah untuk mengetahui : (1) Besarnya biaya dan penerimaan pada usahatani cabai merah (2) profitabilitas dan R/C pada usahatani cabai merah. Metode yang digunakan dalam penelitian ini adalah metode survai dengan mengambil lokasi secara purposif di Desa Kecamatan Panjalu Kabupaten Ciamis. Penarikan sampel dalam penelitian ini adalah secara contoh acak kelompok (cluster random sampling). Dari jumlah populasi di sepuluh kelompoktani yang ada di lima desa di Kecamatan Panjalu diambil sebanyak 34 orang responden dari 170 orang yang melakukan usahatani cabai merah atau sebanyak 20 persen dari setiap anggota kelompok tani. Data dari responden ditabulasi dan dianalisis secara deskriptif. Hasil analisis menunjukkan : (1) Besarnya biaya produksi total (TC) pada usahatani cabai merah di Kecamatan Panjalu sebesar Rp 34.718.273,25 per hektar per musim tanam, dengan penerimaan sebesar Rp. 147.699.443,41 per hektar per musim tanam; (2) Besarnya profitabiltas usahatani cabai merah per hektar per musim tanam di Kecamatan Panjalu sebesar Rp. 112.981.170,16 dengan R/C 4,25.
\end{abstract}

Kata kunci: usahatani, cabai merah, profitabilitas, R/C

\section{PENDAHULUAN}

Cabai (Capsicum annuum) merupakan komoditas komersial karena sebagian besar ditujukan untuk memenuhi kebutuhan pasar. Cabai dapat dikonsumsi dalam bentuk segar maupun olahan. Usahatani cabai dapat dikembangkan untuk memenuhi kebutuhan rumah tangga dan industri pengolahan. Cabai merupakan salah satu komoditas sayuran yang dapat dipasarkan dalam bentuk segar maupun olahan (Santika, 2001).

Usahatani cabai merah di Kabupaten Ciamis telah diusahakan pada di 21 kecamatan dari 36 kecamatan dengan lahan yang diusahakan 421 hektar, menghasilkan cabai merah sebesar 36.784 kwintal dengan produktivitas rata-rata 87,37 kwintal per hektar. Kecamatan Panjalu memiliki luas panen seluas 57 hektar dengan produksi sebesar 5.320 kwintal dan produktivitas sebesar 93,33 kwintal per hektar. Kegiatan usahatani cabai merah di Kecamatan Panjalu diusahakan di 10 kelompoktani dengan anggota sebanyak 170 orang (Dinas Pertanian Tanaman Pangan Kabupaten Ciamis, 2012).

Usahatani yang dilaksanakan diharapkan dapat dilakukan dengan biaya produksi minimal, namun dihasilkan profit yang maksimum. Biaya sarana produksi dapat dikendalikan melalui alokasi jumlah yang tepat, sehingga setiap infut sarana produksi dapat digunakan dengan efisien. Profit maksimum usahatani diharapkan dapat dicapai melalui efisiensi tersebut.

\section{TINJAUAN PUSTAKA}

Usahatani merupakan suatu kegiatan yang dilakukan oleh petani dalam rangka mengusahakan dan mengkoordinir faktor-faktor produksi berupa lahan, tenaga kerja dan modal sehingga memberikan manfaat sebaik-baiknya dan memberikan hasil yang maksimal serta berkelanjutan (Suratiyah, 2006).

Selanjutnya Suratiyah (2006) menyatakan bahwa usahatani adalah himpunan dari sumbersumber alam yang terdapat di tempat itu yang diperlukan untuk produksi pertanian seperti tumbuhan, tanah dan air, perbaikan-perbaikan yang telah dilakukan di atas tanah, dan sebagainya.

Usahatani tidak dilakukan begitu saja, apabila usahatani ingin berjalan lancar maka perlu adanya konsep mengenai usahatani. Suratiyah (2006) menyatakan, konsep usahatani merupakan serangkain proses pengambilan keputusan tentang segala sesuatu yang akan dilakukan dalam usahatani yang akan datang dan rencana-rencana usahatani berupa pernyataan tertulis yang memuat sesuatu yang akan dikerjakan pada periode waktu tertentu untuk tujuan tertentu sesuai dengan usahatani yang dilakukannya. 


\section{MIMBAR \\ A GRIBISNIS \\ ISSN 2460-4321}

Volume 1・Nomor 1・Juli 2015

Profitabilitas atau pendapatan usahatani digambarkan sebagai sisa pengurangan nilainilai penerimaan usahatani dengan biaya yang dikeluarkan, yang mana penerimaan adalah hasil perkalian dari jumlah total produksi dengan harga produk, sedangkan pengeluaran atau biaya usahatani adalah nilai penggunaan sarana produksi dan lain-lain yang diperlukan atau dibebankan kepada proses produksi yang bersangkutan (Soekartawi 2002).

Biaya merupakan salah satu komponen penting dalam setiap proses produksi, seperti halnya dalam usahatani cabai merah. Biaya produksi adalah semua pengeluaran yang diperlukan untuk menghasilkan sejumlah produk tertentu dalam satu kali proses produksi. Biaya produksi dapat digolongkan atas dasar hubungan perubahan volume produksi, yaitu biaya tetap dan biaya variabel. Biaya tetap merupakan biaya yang besar kecilnya tidak dipengaruhi oleh besar kecilnya produksi, sedangkan biaya variabel adalah jenis biaya yang besar kecilnya dipengaruhi oleh besar kecilnya produksi (Suratiyah, 2006).

Soekartawi (2002) menjelaskan bahwa penerimaan adalah nilai semua produk yang dihasilkan dari suatu usahatani dalam satu periode tertentu, misalnya satu musim tanam (MT), atau dalam satuan tahun kegiatan usaha.

\section{METODE PENELITIAN}

Metode penelitian yang dilaksanakan dalam penelitian adalah metode survei dengan lokasi penelitian dilaksanakan di Kecamatan Panjalu Kabupaten Ciamis. Kecamatan Panjalu dipilih secara sengaja (purposif) sebagai lokasi penelitian dengan pertimbangan memiliki jumlah kelompoktani dan jumlah anggota terbanyak di Kabupaten Ciamis.

Sasaran penelitian ini meliputi petani yang melaksanakan usahatani cabai merah di
Kecamatan Panjalu dengan teknik penarikan sampel yang digunakan adalah metode pengambilan contoh acak kelompok (cluster random sampling). Dalam penelitian ini diambil sebanyak 34 orang responden (20\%) dari anggota populasi sebanyak 170 orang.

Profitabilitas merupakan selisih antara penerimaan (TR) dan biaya total (TC) dinyatakan dalam rumus :

$$
\begin{aligned}
\text { Pd }= & \text { TR }- \text { TC } \\
& \text { TC }=\text { FC }+ \text { VC } \\
& \text { TR }=\text { Y.Py }
\end{aligned}
$$

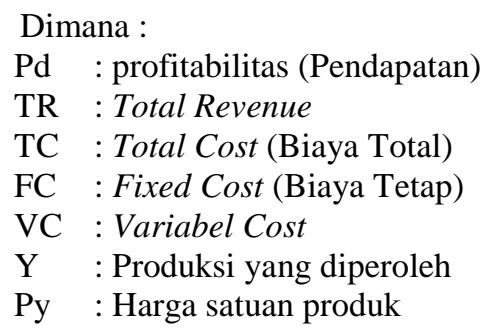

\section{HASIL DAN PEMBAHASAN \\ Penggunaan Luas Lahan dan Sarana Produksi}

Rata-rata penggunaan lahan untuk usahatani cabai merah di kecamatan panjalu adalah seluas 1,69 hektar dengan penggunaan tersempit 0,5 hektar dan terluas 3,8 hektar, sebagian besar responden berada dalam katagori lahan luas. Hernanto (2002) menyatakan, bahwa penguasaan lahan kurang dari 0,5 hektar termasuk kategori sempit, antara 0,5 - 1 hektar termasuk kategori sedang dan apabila lebih dari 1 hektar termasuk kategori yang luas. Penggunaan sarana produksi untuk usahatani cabai merah diantaranya adalah benih, pupuk kandang, mulsa, rata-rata penggunaan sarana produksi dapat dilihat pada Tabel 1.

Tabel 1. Penggunaan Sarana Produksi pada Usahatani Cabai di Kecamatan Panjalu per Hektar per Musim Tanam

\begin{tabular}{|l|l|r|r|r|r|}
\hline \multirow{2}{*}{ No. } & \multirow{2}{*}{ Sarana produksi } & \multicolumn{4}{|c|}{ Penggunaan } \\
\cline { 3 - 6 } & & Terbesar & Terkecil & Rata-rata & $\begin{array}{c}\text { Rata-rata } \\
\text { per hektar }\end{array}$ \\
\hline 1. & Benih (Gr) & 585 & 75 & 256,18 & 151,48 \\
\hline 2. & Pupuk Kandang $(\mathrm{Kg})$ & 23.000 & 4.000 & $12.139,71$ & $7.178,26$ \\
\hline 3. & Pupuk Urea $(\mathrm{Kg})$ & 250 & 15 & 92,38 & 54,63 \\
\hline 4. & Pupuk SP-36(Kg) & 161 & 20 & 71,51 & 42,29 \\
\hline 5. & Pupuk KCL $(\mathrm{Kg})$ & 180 & 50 & 89,06 & 52,66 \\
\hline
\end{tabular}


MOCHAMAD RAMDAN

\begin{tabular}{|l|l|r|r|r|r|}
\hline 6. & Pupuk Daun $(\mathrm{lt})$ & 35 & 5 & 16,50 & 9,76 \\
\hline 7. & NPK $(\mathrm{Kg})$ & 340 & 20 & 151,91 & 95,83 \\
\hline 8. & Kapur $(\mathrm{Kg})$ & 2.000 & 200 & 685,44 & 405,30 \\
\hline 9. & Insektisida (lt) & 30 & 5 & 11,13 & 6,58 \\
\hline 10. & Fungisida $(\mathrm{Kg})$ & 45 & 5 & 15,24 & 9,01 \\
\hline 11. & Kalsium $(\mathrm{Kg})$ & 30 & 3 & 11,32 & 6,70 \\
\hline 12. & Mulsa $(\mathrm{Kg})$ & 255 & 50 & 120,09 & 71,01 \\
\hline 13. & Polybag $(\mathrm{Kg})$ & 5 & 2 & 2,93 & 1,73 \\
\hline 14. & Bumbungan $(\mathrm{m})$ & 60 & 10 & 21,06 & 12,45 \\
\hline
\end{tabular}

Keadaan Usahatani Cabai Merah di Kecamatan Panjalu Kabupaten Ciamis

Berdasarkan hasil penelitian yang telah dilakukan terhadap petani, usahatani yang dilakukan di Kecamatan Panjalu umumnya dilakukan secara seragam, Varietas yang ditanam petani terdiri dari Long Chili dan Hot Beauty. Varietas tersebut termasuk varietas unggul yang cocok ditanam di dataran sedang sampai tinggi. Penyemaian dilakukan dengan menggunalan kantong plastik (polybag) dengan media terdiri dari campuran pupuk kandang dengan tanah.

Benih disemai satu benih untuk satu polibag. Lamanya benih dipersemaian antara 3 sampai 4 minggu. Kemudian dipindahkan ke lapangan atau lahan. Penanaman dilakukan di atas bedengan berukuran lebar 1 meter yang telah ditutup dengan mulsa plastik. Pelubangan mulsa dan pembuatan lubang tanam dilakukan sesaat sebelum penanaman bibit, jarak tanam yang digunakan umumnya $60 \times 70$ sentimeter. Bibit ditanam pagi atau sore hari, penanaman dilakukan secara monokultur.

Pemeliharaan meliputi kegiatan-kegiatan sebagai berikut :

a. Pemasangan ajir

Ajir yang digunakan berupa bilahan bambu yang berukuran tinggi 1 sampai 1,2 meter, ditancapkan sekitar 15 sentimeter dari pokok batang tanaman, satu ajir untuk satu lubang tanaman.

\section{b. Penyulaman}

Penyulaman dilakukan untuk mengganti tanaman yang pertumbuhannya tidak normal, terserang hama atau penyakit serta tanaman yang mati. Bibit yang digunakan berasal dari bibit cadangan. Penyulaman dilakukan pada umur 7 hari setelah tanam.

c. Penyiangan

Untuk mencegah terjadi persaingan rumput liar dengan tanaman pokok dilakukan penyiangan terutama di dekat batang tanaman yang tidak tertutup mulsa dan di bagian pinggir bawah bedengan secara manual atau menggunakan kored. Rata-rata penggunaan mulsa per hektar sebanyak 71,01 meter.

d. Pemupukan susulan

- Pupuk yang digunakan adalah NPK, dengan cara dilarutkan dengan air kemudian disiramkan menggunakan emrat, dilakukan setiap 14 hari setelah tanaman berumur satu bulan.

- Pemberian pupuk pelengkap cair (PPC), diberikan melalui daun pada saat tanaman berumur 4 sampai 7 minggu setelah tanam. Pupuk yang digunakan Gandasil D dengan cara dilarutkan dengan air dan disemprotkan ke daun dengan menggunakan alat sprayer.

- Pemberian zat pengatur tumbuh (ZPT) Zat pengatur tumbuh yang digunakan adalah Atonik 6,5 dan Dharmasri 5 EC. Atonik 6,5. Zat pengatur tumbuh ini diberikan pada saat tanaman berumur 30, 50 dan 72 hari setelah tanam. Sedangkan Dharmasri 5 EC diberikan dengan dengan cara disemprotkan menggunakan sprayer pada saat tanaman berumur 21,42 dan 62 hari setelah tanam.

e. Pengairan

Agar tanaman tidak kekeringan terutama pada musim kemarau, pengairan yang dilakukan petani dengan cara di leb yaitu mengalirkan air ke parit-parit bedengan selama 4 sampai 5 jam.

f. Perompelan tunas

Kegiatan ini dilakukan dengan cara membuang tunas air yang tumbuh di bagian ketiak daun sebelah bawah. Tunas yang tumbuh di atas percabangan tidak dirompel. Selain itu bunga yang muncul pertama kali dibuang agar tidak mengganggu pertumbuhan cabang. Prompelan dilakukan pada saat tanaman berumur 8 sampai 10 hari.

g. Pengendalian 


\section{AIMBAR \\ Agribisnis \\ ISSN 2460-4321}

Volume $1 ・$ Nomor $1 ・$ Juli 2015

Pengendalian hama dan penyakit juga merupakan salah satu penunjang keberhasilan dalam usahatani cabai, yakni dengan menggunakan insektisida dan fungisida kimia. Ini dilakukan dengan harapan dapat mengurangi gangguan hama dan penyakit yang dapat menyebabkan kerusakan pada tanaman cabai atau bahkan bisa menyebabkan kegagalan panen.

h. Panen

Karena Kecamatan Panjalu merupakan daerah dataran tinggi, pemanenan dilakukan setelah tanaman cabai berumur antara 90-100 hari setelah tanam atau dirasa sudah matang, rata-rata setiap hektar lahan tanaman cabai dapat menghasilkan sebanyak 9.135,03 kilogram per musim tanam. Setelah itu dilakukan pemilahan (gradding) untuk memisahkan antara yang berkualitas baik dan tidak, selanjutnya cabai akan dijual di kelompok tani atau ke pedagang kecil dan besar.

Profitabilitas atau pendapatan merupakan selisah antara penerimaan total dengan biaya total, dimana penerimaan total merupakan perkalian antara jumlah produksi yang dihasikan dengan harga jual produk, sedangkan biaya total merupakan penjumlahan dari biaya tetap dan biaya variabel. Hasil analisis profitabiltas sebagai berikut:

a. Analisis Biaya
Biaya produksi adalah korbanan yang digunakan dalam proses produksi untuk menghasilkan produk, yang diukur dengan uang atau rupiah. Biaya total pada usahatani cabai terdiri dari biaya tetap dan biaya variabel. Biaya tetap meliputi biaya yang dikeluarkan untuk pembayaran PBB (Pajak Bumi dan Bangunan), penyusutan alat, dan pembayaran bunga atas modal, sedangkan biaya variabel meliputi biaya untuk pembelian benih, pupuk (kandang, urea, SP-36, KCL dan pupuk Daun) Kapur, Insektisida, Fungisida, Kalsium, Mulsa, Polybag, Bumbungan dan tenaga kerja. Data selengkapnya mengenai rata-rata biaya pada usahatani cabai di Kecamatan Panjalu dapat dilihat pada Tabel 2.

Tabel 2 menunjukkan biaya total produksi (TC) sebesar $\mathrm{Rp} 34.718 .273,25$, dari biaya tersebut digunakan untuk biaya tetap total (TFC) sebesar $\quad$ Rp 1.344.574,00 dan variabel total (TVC) sebesar Rp 33.373.702,25. Biaya terbesar pada biaya tetap adalah biaya untuk penyusutan alat yang digunakan sebesar Rp. 1.183.463,20. Banyaknya jumlah biaya penyusutan ini dikarenakan banyaknya alat yang digunakan dalam usahatani cabai merah di Kecamatan Panjalu seperti cangkul, pompa air, blower, ataupun selang. Sedangkan biaya variabel terbesar adalah biaya untuk pembelian muLsa sebesar Rp 17.044.063,08.

Tabel 2. Penggunaan Biaya, pada Usahatani Cabai di Kecamatan Panjalu per Hektar per Musim Tanam

\begin{tabular}{|c|l|r|}
\hline No & \multicolumn{1}{|c|}{ Uraian } & Jumlah \\
\hline 1. & Biaya Tetap : & \\
& - PBB (Rp) & $85.000,00$ \\
& - Penyusutan alat (Rp) & $1.183 .463,20$ \\
& - Bunga Modal (Rp) & $76.107,80$ \\
& Jumlah Biaya Tetap (TFC) (Rp) & $1.344 .571,00$ \\
\hline 2. & Biaya variabel : & \\
& - Benih (Rp) & \\
& - Pupuk Kandang (Rp) & $1.082 .486,09$ \\
& - Pupuk Urea (Rp) & $3.497 .680,89$ \\
& - Pupuk SP-36 (Rp) & $538.181,82$ \\
& - Pupuk KCL (Rp) & $823.792,21$ \\
& - Pupuk Daun (Rp) & $329.081,63$ \\
& - NPK (Rp) & $1.179 .962,89$ \\
& - Kapur (Rp) & $479.128,01$ \\
& - Insektisida (Rp) & $32.511,60$ \\
& - Fungisida (Rp) & $912.894,25$ \\
\hline
\end{tabular}




\begin{tabular}{|c|l|r|}
\hline & - Kalsium (Rp) & $128.571,43$ \\
& - Mulsa (Rp) & $17.044 .063,08$ \\
& - Polybag (Rp) & $55.380,33$ \\
& - Bumbungan (Rp) & $132.838,59$ \\
& - Tenaga kerja (Rp) & $4.094 .805,19$ \\
& - Bunga modal & $1.889 .077,49$ \\
& Biaya Variabel Total (TVC) (Rp) & $33.373 .702,25$ \\
\hline \multirow{2}{*}{3.} & \multicolumn{1}{|c}{ Biaya Total (TC) } & $34.718 .273,25$ \\
\hline
\end{tabular}

\section{Analisis Penerimaan, Pendapatan dan R/C Usahatani Cabai Merah}

Kegiatan usahatani cabai merah di Kecamatan Panjalu selama satu musim tanam dari mulai persiapan lahan sampai dengan panen terakhir berlangsung selama 6 bulan. Dalam kegiatan usahatani cabai merah tujuannya adalan untuk mendapatkan profit atau keuntungan. Keuntungan diperoleh dari hasil penguran antara penerimaan dan biaya. Penerimaan total merupakan hasil perkalian antara produksi yang dihasilkan dengan harga jual produk. Produksi yang dihasilkan pada usahatani cabai per musim tanam sebanyak 14.769,94 kilogram per hektar dengan harga jual sebesar Rp. 10.000,- per kilogram, sehingga penerimaan total yang diterima sebesar Rp. 147.699.443,41 per hektar. Sedangkan besarnya pendapatan yang diperoleh petani di Kecamatan Panjalu dalam melaksanakan usahatani cabai adalah sebesar Rp. 112.981.170,16 per hektar.

$\mathrm{R} / \mathrm{C}$ merupakan imbangan antara total penerimaan dengan total biaya yang dikeluarkan dan digunakan untuk melihat kelayakan suatu usaha yang dilakukan. Ratarata nilai $\mathrm{R} / \mathrm{C}$ pada usahatani cabai di Kecamatan Panjalu sebesar 4,25 yang menunjukkan bahwa setiap Rp. 1 biaya yang dikeluarkan akan diperoleh penerimaan sebesar Rp. 4,25 sehingga pendapatannya sebesar Rp. 3,25 . Nilai R/C 4,25 menunjukkan bahwa usahatani cabai tersebut sangat menguntungkan dan layak untuk diusahakan.

\section{PENUTUP}

\section{Kesimpulan}

Berdasarkan hasil dan penelitian dan pembahasan, maka dapat ditarik kesimpulan sebagai berikut :

1. Besarnya biaya produksi total (TC) pada usahatani cabai merah di Kecamatan Panjalu sebesar $\mathrm{Rp}$ 34.718.273,25 per hektar per musim tanam, dengan penerimaan sebesar Rp. 147.699.443,41 per hektar per musim tanam

2. Besarnya profitabiltas usahatani cabai merah per hektar per musim tanam di Kecamatan Panjalu sebesar Rp. 112.981.170,16 dengan R/C 4,25

\section{Saran}

Berdasarkan kesimpulan, maka disarankan:

1. Agar lebih menguntungkan dan untuk mengoptimalkan produksi dan pendapatan pada usahatani cabai, diperlukan pelatihan secara intensif guna meningkatkan pengetahuan petani dalam berusahatani cabai yang lebih berorientasi bisnis.

2. Kepada petani perlu memperhitungkan penggunaan mulsa

\section{DAFTAR PUSTAKA}

Arikunto, Suharsimi. 2002. Prosedur Penelitian Suatu Pendekatan Praktik. Rineka Cipta. Jakarta.

Balai Penyuluhan Pertanian, Perikanan dan Kehutanan (BP3K) Kecamatan Panjali, 2011. Programa BP3K Kecamatan Panjalu 2011. Ciamis

Boediono. 2002. Ekonomi Mikro: Seri Sinopsis Pengantar Ilmu Ekonomi No.1. BPFE. Yogyakarta.

Daniel, M. 2002. Metode Penelitian Sosial Ekonomi. PT Bumi Aksara. Jakarta.

Dinas Pertanian Tanaman Pangan Kabupaten Ciamis, 2012. Laporan Tahunan 2011. Pemerintan Provinsi Jawa Barat. Bandung.

Kurniawan, A.Y., Hartoyo, S., dan Syaukat, Y. 2008. Analisis Efisiensi Ekonomi dan Daya Saing Jagung pada Lahan Kering di Kabupaten Tanah Laut, Kalimantan Selatan. Forum Pascasarjana, Vol. 31, No. 2, 2 April 2008:93-103. IPB. Bogor.

Mandaka, S., dan Hutagaol, M.P. 2005. Analisis Fungsi Keuntungan, Efisiensi Ekonomi dan Kemungkinan Skema Kredit Bagi Pengembangan Skala Usaha Peternakan 


\section{AIMBAR \\ Agribisnis \\ ISSN 2460-4321}

Volume $1 ・$ Nomor $1 ・$ Juli 2015

Sapi Perah Rakyat di Kelurahan Kebon

Pedes, Kota Bogor. Jurnal Agro Ekonomi,

Volume 23 No.2, Oktober 2005 : 191-208.

IPB. Bogor.

Santika, Adhi. 2001. Agribisnis Cabai. Penebar Swadaya. Jakarta.

Satyarini, T.B.. 2009. Analisis Kelayakan

Usahatani Cabai di Lahan Pantai (Studi

Kasus di Pantai Pandan Simo, Bantul,

Daerah Istimewa Yogyakarta). Pusat

Analisis Sosial Ekonomi dan Kebijakan

Pertanian. Badan Penelitian dan

Pengembangan Pertanian. Departemen Pertanian RI. Jakarta.

Soekartawi. 2001. Pembangunan Pertanian.

Raja Grafindo Persada. Jakarta.

2002. Teori Ekonomi Produksi. Raja

Grafindo Persada Jakarta.

Winarno, M., dan Hardjanto, T. 2002.

Usahatani Cabai. Dalam Seri Agribisnis

Cabai. Editor: Santika, A. Penebar

Swadaya. Jakarta. 